\title{
Life-history constraints in inaccurate Batesian myrmecomorphic spiders (Araneae: Corinnidae, Gnaphosidae)
}

\author{
STANO PEKÁR and MARTIN JARAB \\ Department of Botany and Zoology, Faculty of Science, Masaryk University, Kotlá řská 2, 61137 Brno, Czech Republic; \\ e-mail: pekar@sci.muni.cz
}

Key words. Formicidae, prey, trophic niche, clutch size, copulation, courtship

\begin{abstract}
Accurate Batesian mimicry is known to impose constraints on some traits of the mimic, such as foraging or reproductive behaviour. It is not known whether life-history traits of inaccurate Batesian mimics are constrained as well. We studied selected lifehistory traits of three spider species, Liophrurillus flavitarsis, Phrurolithus festivus (both Corinnidae), and Micaria sociabilis (Gnaphosidae), that are inaccurate mimics of ants. Namely, we were interested in how myrmecomorphy (ant-like resemblance) constrains their circadian activity, trophic niche and reproductive behaviour. The spiders were found to have diurnal activity like their models, whereas their close relatives have nocturnal activity. The three mimics do not catch ants, nor do they use food resources of ants, but catch various tiny invertebrates that occur in the vicinity of their models. Their trophic niche seems to be constrained by occurrence among ants. Absence of courtship and long lasting copulation, in a position that does not provide protective resemblance, do not seem to be constrained by mimicry in the three species. Comparative analysis of fecundity in mimetic and non-mimetic spiders showed that clutch size is also not constrained. Unlike in accurate mimics, life-history traits of inaccurate myrmecomorphs appear not to be constrained.
\end{abstract}

\section{INTRODUCTION}

In Batesian mimicry a species resemble a low-profit (often noxiuos) model in order to gain protection from model-averse predators (e.g., Edmunds, 1974). Batesian mimicry is present in various taxa and is of varying quality of imitation (e.g. Ruxton et al., 2004). The mimic can imitate its model either very closely and become an accurate mimic or crudely and become an inaccurate mimic. Several hypotheses have been suggested to explain the evolution and maintenance of inaccurate mimics (Dittrich et al., 1993; Holen \& Johnstone, 2004; Gilbert, 2005; Johnstone, 2005), or generalised mimics sensu Reiskind (1970). Yet, only a few of these have been applied to spiders (Edmunds, 2000; Pekár \& Král, 2002; Pekár \& Jarab, 2011).

Inaccurate Batesian mimics are often found in systems where the model and the mimic are distantly phylogenetically related, e.g. wasps and flies or ants and true bugs, because accurate resemblance would involve dramatic change in their body plan. Spiders resemble various unrelated models, such as caterpillars (Exline \& Levi, 1962), woodlice (Levi, 1965), termites (Jocqué, 1994), mutilid wasps (e.g., Edwards, 1984), or beetles (e.g., CloudsleyThompson, 1995). But the majority of spider mimics imitate ants (see Cushing, 1997 for overview). Accuracy of the myrmecomorphic spiders is variable, from species showing barely any resemblance to the model to accurate mimics (Wunderlich, 1994). Inaccurate ant-mimics resemble their model in colour pattern only, not by morphological structures.

Ants are a frequent model not only for spiders. Antmimicry, or myrmecomorphy, was found in mantids, grasshoppers, true bugs and beetles (Edmunds, 1974; McIver \& Stonedahl, 1993). Unprofitability of ants comes from their aggression performed by collective attack using mandibles and their production of various defensive secretions (Hölldobler \& Wilson, 1990). Due to the slender body and production of chemical defences, ants might be low profitable prey also from a nutritional and energetic point of view (McNab, 1984). Being wingless, ant workers are suitable models for species whose body plan lacks wings. Furthermore, ants are preyed upon only by a few specialised predators (e.g., Hölldobler \& Wilson, 1990).

Selection for accurate resemblance can entail dramatic changes in the phenotype, such as body size, body shape, colour pattern, and behaviour (Holen \& Johnstone, 2004). Yet, very little is known how the changes can constrain life-history traits. Morphological resemblance may result in various fitness costs. For example, hoverflies that imitate the contrasting black-yellow pattern of wasp models may compromise their thermoregulatory abilities, in particular during cooler seasons (Heal, 1989). In myrmecomorphs imitation involves the evolution of a slender body so it is expected that mimics have reduced fecundity (Edmunds, 1978; McIver \& Stonedahl, 1993).

Behavioural resemblance can result in reduction of other activities, for example, mating (Turner, 1978). In spiders resembling ants, the mimic should share the same ecological environment and possess temporal cooccurrence with its model (McIver \& Stonedahl, 1993). Furthermore, as the resemblance is enhanced by a locomotion imitating that of ants (Ceccarelli, 2008; Pekár \& Jarab, 2011), inaccurate ant-mimicking spiders should avoid being stationary. This may constrain their (1) cir- 
cadian activity, as ant-mimicking spiders must be active during the same time period as their models; (2) trophic niche, which may include only their model or prey associated with ants; and (3) reproductive biology, such as mating that should be performed either in a sheltered place or be of short duration.

In our study we used three spider species that are inaccurate mimics of ants (Bonaric, 1974; Wunderlich, 1994; Pekár \& Jarab, 2011): Liophrurillus flavitarsis (Lucas), Phrurolithus festivus (C.L. Koch) (both Corinnidae), and Micaria sociabilis Kulczyński (Gnaphosidae). Each of these species belongs to a different genus: they imitate their models only in colour; and do not posses any body constrictions, altered eye pattern, or shifted appendages. Our aim was to evaluate selected life-history traits, such as circadian activity, trophic niche and reproductive biology, in order to reveal whether these might be constrained by Batesian mimicry.

\section{MATERIAL AND METHODS}

Each species of mimic was collected and studied at one site: L. flavitarsis in Mitra near Évora (southern Portugal), P. festivus in Brno (Czech Republic), and M. sociabilis in Lednice (Czech Republic). At study sites we examined the association of these spiders with ants by census recording and found these mimics to associate closely with one or two species of ants. L. flavitarsis was found most frequently with Aphaenogaster senilis Mayr ants, P. festivus with Lasius platythorax Seifert ants, and $M$. sociabilis with only Liometopum microcephalum (Panzer) ants (Pekár \& Jarab, 2011). Spiders were identified using Wunderlich $(1979,1992)$ and Heimer \& Nentwig (1991). Ants were identified using Seifert (1996) and Collingwood \& Prince (1998).

The circadian activity of spiders and ants was observed from April to October, approximately twice a month. We found that the spiders and ants are active during the day throughout the season, thus we performed a detailed study of their circadian activity on a sunny day in May when the spiders were mature. We studied the activity of one model species with which each spider species most frequently associates. The number of active spider individuals (seen during $5 \mathrm{~min}$ in an area of $0.67 \mathrm{~m}^{2}$ ) and the number of active ant individuals (seen during $30 \mathrm{~s}$ in an area of $\left.0.18 \mathrm{~m}^{2}\right)$ around ant foraging trails near $(50 \mathrm{~cm}$ around) five nest entrance (of each ant species) was recorded every hour between 04:00 and 24:00, i.e. $3 \mathrm{~h}$ before or after the onset or decline of spiders' activity. Spearman correlation was used to study the relationship between abundance of spiders and ants.

The trophic niche of these spider species was investigated both in the field and in the laboratory. In the field each collected specimen was observed and, using a magnifying lens, we recorded whether it was feeding on any prey. Remnants of any prey were then collected and identified. As the chance to find a cursorial spider with its prey is very low (about 5\% Huseynov, 2006), we investigated their prey choice in the laboratory. For this purpose we brought 20 adult female specimens of each spider species into the lab and kept them in glass tubes with a layer of plaster of Paris at the bottom that was moistened regularly. Then the spiders were released into a plastic Petri dish (diameter $40 \mathrm{~mm}$ ) and offered a range of prey species chosen from their potential prey. In the field we estimated the potential prey (i.e. invertebrates smaller than the body length of the spiders) by census recording in an area of $1 \mathrm{~m}^{2}$ around three model nests. We found that the potential prey were dominated by Formicidae (their models), followed by Collembola, Cicado- morpha, Diptera, Heteroptera, Araneae, Coleoptera and Blattodea. In the experiments we used Formicidae, both their models (A. senilis, L. platythorax, L. microcephalum), and other tiny ants (Pheidole sp. or Tetramorium sp.), collembolans (Sinella curviseta Brooks), flies (micropterous Drosophila melanogaster Meigen), mites (Trombiculidae), spiders (Araneidae spiderlings), aphids (Aphis fabae Scopoli), woodlice (Armadillidium sp.), beetle larvae (Tribolium confusum Jacquelin du Val), and Zygentoma. Each specimen was offered one individual of each prey species in a 2-day interval. Size (total body length) of both spiders and prey were recorded. Capture frequency was assessed $2 \mathrm{~h}$ following release.

To investigate reproductive traits, we collected 10 adult males and 10 subadult females of each species and reared them in the laboratory. Spiders were reared on a diet of Collembola (S. curviseta) and fruit flies (micropterous D. melanogaster) until reaching adulthood. Prior to mating a pair of adult spiders were released to a Petri dish (diameter $5 \mathrm{~cm}$ ). The mating position and the duration of mating were recorded. Females were reared for three weeks until they laid egg sacs. Eggsacs were opened and the clutch size was recorded.

We collected published data on clutch size of other inaccurate spider mimics from Gnaphosidae and Corinnidae (Kaston, 1948; Nielsen, 1932), combined them with our results and compared them with the clutch size of related non-mimetic gnaphosid and clubionid/liocranid spider species (Marshall \& Gittleman, 1994; Zolnerowich \& Horner, 1985), by means of ANCOVA, thus taking into account female size. Clubionid and liocranid species were chosen because no data were available for non-mimetic corinnid species.

\section{RESULTS}

\section{Circadian activity}

The spiders were seen upon the surface of the soil or bark during the day, at other times they hide in bark crevices, in litter, or under stones. The circadian activity of all three spider mimics began at 07:00 and terminated at 21:00, thus their activity fell within that of their models (Fig. 1). Specifically, the activity of Aphaenogaster ants was bimodal, one peak at noon and the other in the evening (Fig. 1A). Thus activity of Liophrurillus spiders was not correlated to that of Aphaenogaster (Spearman correlation, $\rho=0.46, \mathrm{~S}=303.2, \mathrm{P}=0.08)$. The activity of Lasius ants had one peak at noon (Fig. 1B). Thus the activity of Phrurolithus correlated with that of Lasius (Spearman correlation, $\rho=0.92, \mathrm{~S}=40.6, \mathrm{P}<0.0001$ ). The activity of Liometopum ants was rather constant from morning until evening (Fig. 1C). Therefore, the activity of Micaria was not correlated with that of Liometopum (Spearman correlation, $\rho=-0.18, \mathrm{~S}=662.6, \mathrm{P}=0.51$ ).

\section{Trophic niche}

We never observed any of the three mimics catch their ant models in the field or take any food resource tended by ants. The spiders captured tiny invertebrates such as mites, flies, springtails $(\mathrm{N}=5$ in $M$. sociabilis, $\mathrm{N}=2$ in $P$. festivus). Nor did we observe the spiders attack any ant species in the laboratory, not even tiny ants. Mimics of all three species accepted a variety of other particularly tiny invertebrates, such as springtails, fruit flies, and homopterans (Fig. 2). The trophic niche thus includes prey smaller than $70 \%$ of spider body size. 

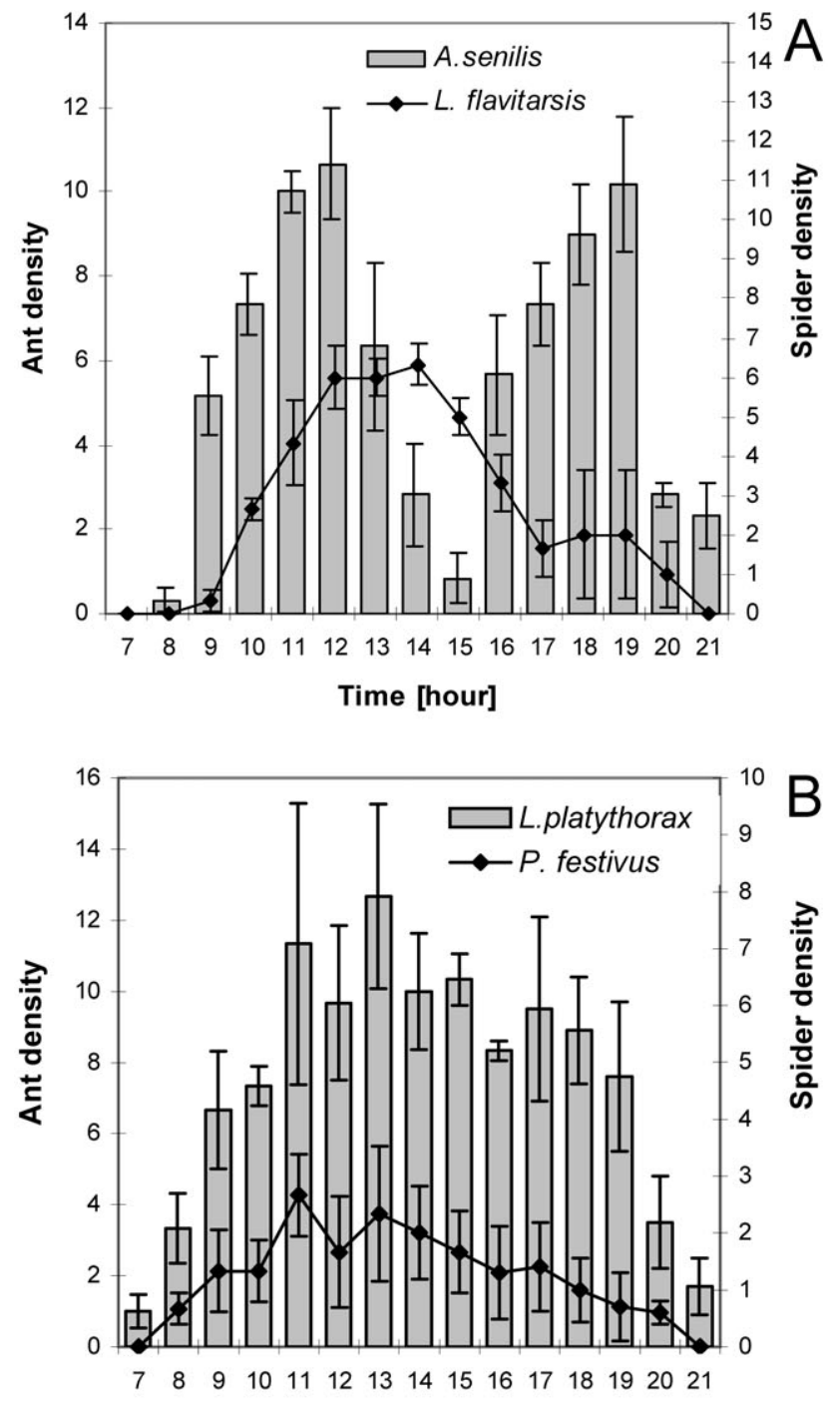

Time [hour]

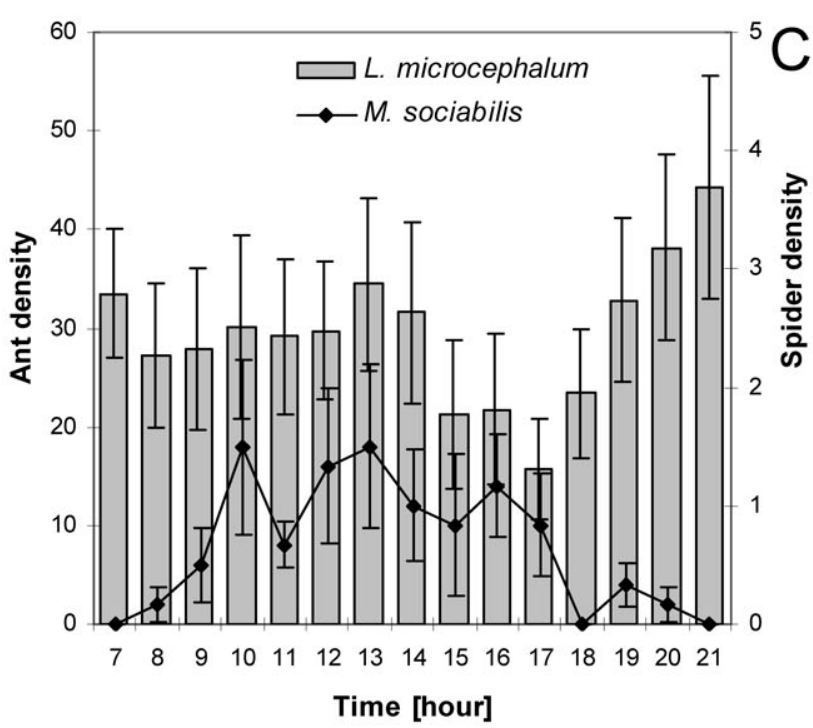

Fig. 1. Circadian activity pattern expressed as density of the spider mimics (L. flavitarsis, P. festivus, M. sociabilis) and their models (A. senilis, L. platythorax, L. microcephalum) observed at the study sites. Hours of inactivity of spiders, before 7:00 and after 21:00, are not shown. Bars - models, points - mimics. Whiskers are SEs of the mean.

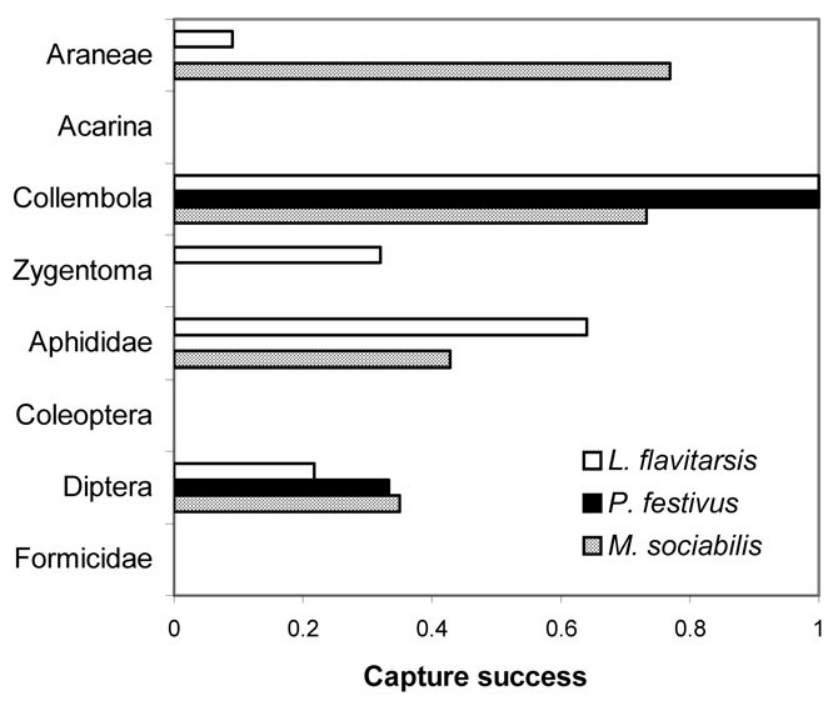

Fig. 2. Comparison of the proportion of captured and consumed prey of three spider mimics (L. flavitarsis, P. festivus, $M$. sociabilis). $\mathrm{N}=20-25$ for each prey item.

\section{Reproduction}

No courtship was observed in any of the three species. The male rushed to a female and immediately after contact began to mate with her. In all three species, the type III mating position [with the male being positioned by the side of the female, Foelix (1996)] was observed (Fig. 3). In the field we observed mating in the open (e.g. on bark): the pair moved slightly but for most of the time it was stationary.

In L. flavitarsis mating lasted on average $84 \pm 4.9 \mathrm{~min}$ $(\mathrm{n}=23)$. The egg clutch included on average 4.7 eggs $\left(\mathrm{CI}_{95}=4.0,5.4 ; \mathrm{n}=20\right)$. In P. festivus mating lasted on average $252 \pm 15.7 \mathrm{~min}(\mathrm{n}=10)$. The egg clutch included on average 4.1 eggs $\left(\mathrm{CI}_{95}=3.7,4.5 ; \mathrm{N}=18\right)$. In $M$. sociabilis mating lasted $35 \pm 8.6 \mathrm{~min}(\mathrm{n}=19)$. The egg clutch included on average 4 eggs $\left(\mathrm{CI}_{95}=2.9,5.1 ; \mathrm{N}=10\right)$. Females of all three species produced more than one eggsac. Specifically, in L. flavitarsis it was on average 1.5 eggsacs ( $\mathrm{SD}=0.5)$, in P. festivus it was 2.1 eggsacs (SD $=1.3)$, and in M. sociabilis it was 2.3 eggsacs $(\mathrm{SD}=1.2)$.

In Gnaphosidae, the relationship between clutch size and female size was similar for inaccurate mimics and non-mimetic species (ANCOVA, $\mathrm{F}_{1,6}=0.02, \mathrm{P}=0.89$, Fig. 4). In Corinnidae/Clubionidae/Liocranidae there was an indication of steeper increase of clutch size on body size in non-mimetic species but the difference was not significant (ANCOVA, $\mathrm{F}_{1,7}=4.8, \mathrm{P}=0.06$ ).

\section{DISCUSSION}

To answer the question whether ant-like mimicry constrains life-history traits of inaccurate mimics, our data had to be compared with non-mimetic species that are phylogenetically related. Unfortunately, for corinnid nonmimetic species such data are not available. Therefore, we chose traits general for the most closely related families, i.e. Clubionidae and Liocranidae. The taxonomic position of Liophrurillus and Phrurolithus was uncertain for a long time (Platnick, 2009), as they once belonged to 

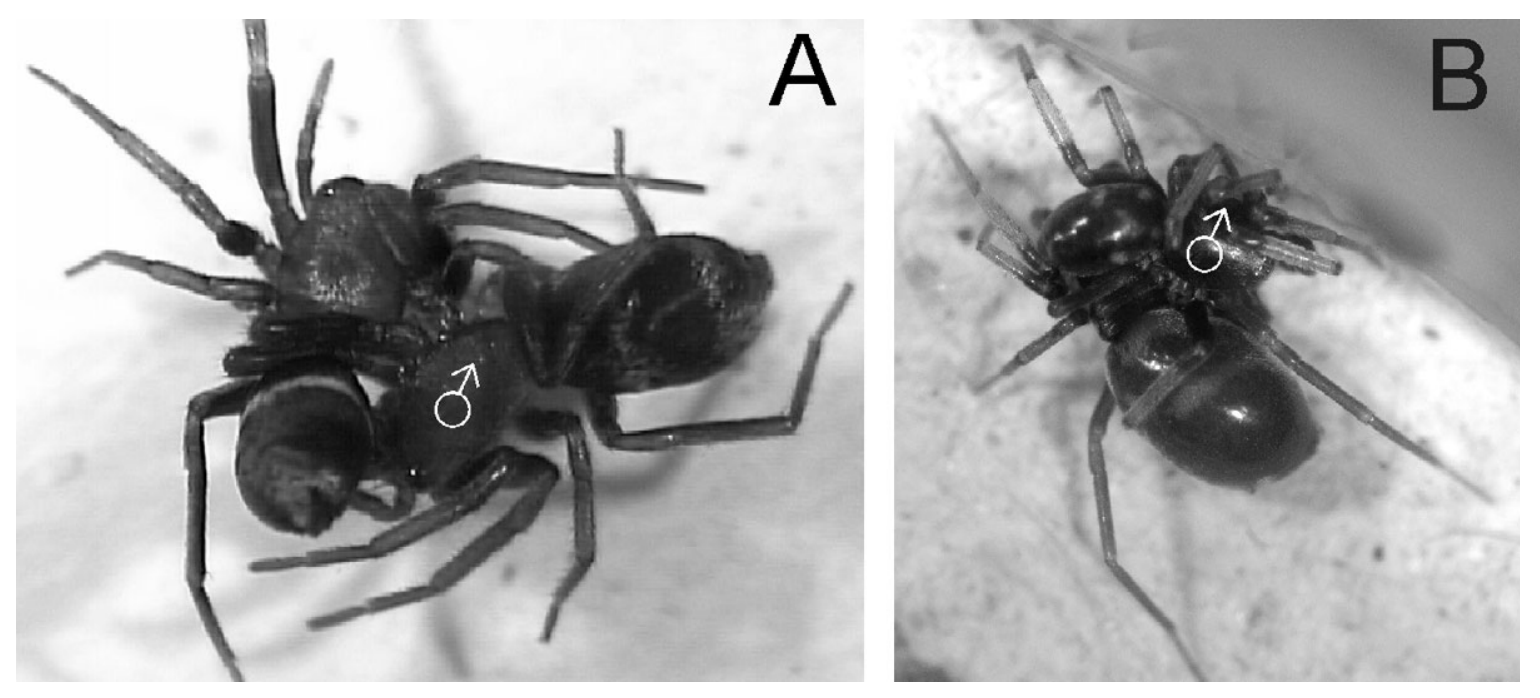

Fig. 3. Mating position of M. sociabilis (A) and P. festivus (B).
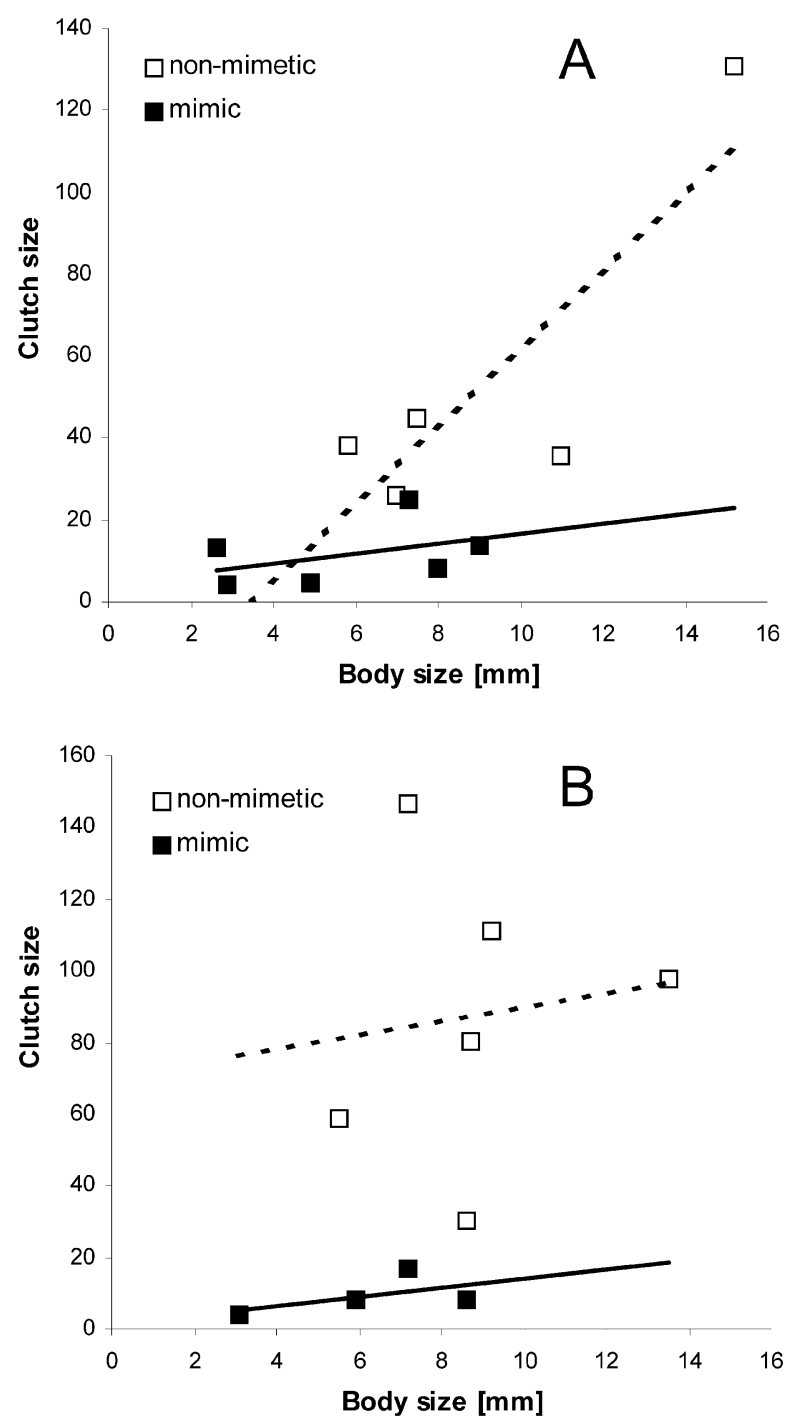

Fig. 4. Comparison of the relationship between the clutch size and the female total body size in inaccurate mimics and in nonmimetic species from a few spider families: Corinnidae / Clubionidae / Liocranidae (A) and Gnaphosidae (B). The linear models for both mimetic (solid line) and non-mimetic (dashed line) species are shown.
Clubionidae and Liocranidae. We will also compare the traits with those for accurate mimics, found in the family Salticidae (Myrmarachne, Synageles) in order to see whether these are similarly constrained.

There should be a strong correlation in the spatial and temporal occurrence of the mimics and their models. The circadian activity of all three mimics reflects that of their models, i.e. it is diurnal. Many closely related non-mimetic gnaphosid and clubionid spiders are, however, nocturnal (Kaston, 1948; Grimm, 1985). Thus the circadian activity of these inaccurate mimics appears to be an adaptation related to the mimicry. A similar selective pressure for an adjustment in activity could apply to other inaccurate ant-mimics, such as species in the genus Zodarion (Pekár et al., 2005). While many non-mimetic species of this genus are nocturnal (e.g. Harkness, 1977), the ant-mimicking species are active during the day (Pekár \& Král, 2002; Pekár et al., 2005). Accurate salticid ant-mimics are diurnal (Engelhardt, 1970; Edmunds, 1978), which is similar to that of their relatives. Thus in these accurate mimics the circadian activity is not constrained.

The trophic niche of the species studied is rather wide but does not include their models. Surprisingly, the mimics refused even tiny ants that fell within the size limits of accepted prey. This is consistent with observations on other myrmecomorphic spider species. For example, Zuniga magna Peckham \& Peckham (Salticidae) and Sphecotypus sp. (Corinnidae) avoided ants (Oliveira, 1988). The observations on natural prey and prey choice experiments performed in our study clearly show that all three species are euryphagous but attack mainly prey smaller than their prosoma. Related gnaphosid and clubionid spiders have a much wider trophic niche that includes ants (e.g., Austin, 1984; Trautner, 1994). Such a constrained niche presumably reflects prey that is available in the vicinity of ants. Tiny invertebrates, such as springtails and mites, are ignored by ants and thus can be exploited by ant-mimics. On the other hand, some inaccurate myrmecomorphic spiders, such as Euryopis episi- 
noides (Walckenaer), Zodarion spp. and Trygetus sexoculatus (O.P.-Cambridge), have even narrower trophic niches including only their model ants (Soyer, 1943; Pekár \& Král, 2002; Pekár et al., 2005).

The trophic niche of accurate ant-mimics can also include only ants, as in Strophius and Aphantochilus (Oliveira \& Sazima, 1985), or other tiny invertebrates but not ant workers, as in Myrmarachne (Edmunds, 1978). Some myrmecomorphic species, namely Myrmarachne melanotarsa Wesolowska et Salm, which lives in close proximity to Crematogaster ants, fed on the honey-dew produced by coccids tended by ants (Jackson et al., 2008). Several species of Myrmarachne were seen to feed on ant pupae on rare occasions (Jackson, 1986; Jackson et al., 2008).

None of the observed reproductive traits appear to be constrained by mimicry. In gnaphosid and clubionid nonmimetic spiders courtship is absent and copulation takes place inside silk cells where the pair is protected from predators (Bristowe, 1941; Pollard \& Jackson, 1982). The copulation lasts from some minutes to a few hours (Grimm, 1985). In the study spiders, mating took place during the day either upon the surface (tree bark or ground) or in sheltered places (in bark crevices and under stones). The mating position, similar to that found in other gnaphosids (Grimm, 1985), does not seem to provide any protective resemblance to the mating pair. In accurate mimics, e.g. Myrmarachne, mating takes place in a silk cell (Edmunds, 1978).

The apparent cost of myrmecomorphy is reduced clutch size, particularly in accurate mimics, i.e. with constriction on the abdomen (Cushing, 1997). In accurate myrmecomorphs, fecundity was lower than in non-mimetic species, specifically in Myrmarachne spiders (Edmunds, 1978) and Coquillettia bugs (McIver \& Stonedahl, 1993). The ant-mimicking salticid, Peckhamia picta (Hentz), lays only 3 eggs in a clutch (Pocock, 1909). However, the clutch size of the three mimics studied here does not differ from those in non-mimetic species (Fig. 4).

Accurate myrmecomorphic species, in which constrictions constrain fecundity, should be selected to have iteroparous reproduction. Synageles sp., for example, lays 7-8 eggsacs (Cutler, 1987). Similar, iteroparous reproduction was observed in other accurate myrmecomorphs (Peckham \& Peckham, 1889; Edmunds, 1978). The inaccurate spiders investigated in this study produced few successive eggsacs, as do other gnaphosids (Kaston, 1948; Grimm, 1985), suggesting that iteroparity has not resulted from myrmecomorphy.

Other life-history traits, such as dispersal, which was not studied here, might be also constrained in inaccurate ant-mimics. Since ant-mimics associate closely with their models, they should use other forms of dispersal than ballooning. Non-mimetic gnaphosid spiders do not balloon, but clubionids do (Blandenier \& Fürst, 1998). Neither inaccurate nor accurate myrmecomorphs have been found in aerial samples.

What are the costs of close association with ants? Myrmecomorphic spiders are rarely attacked by their models
(Jackson et al., 2008). We have witnessed only one attack on M. sociabilis by its model. This is because myrmecomorphic spiders have adaptations that enhance their ability to survive in the presence of ants, such as avoidance of encounters. Experiments, in which ant-mimics were released into colonies of ant models, showed that the mimics had higher survival than non-mimetic spiders (Nelson et al., 2005).

Only some life-history traits, namely circadian activity and trophic niche, were found to be constrained by mimicry in the inaccurate mimics. This is rather similar to constraints imposed on accurate ant-mimics. Thus association with ants seems to provide the inaccurate mimics only with defensive adaptive advantage.

ACKNOWLEDGEMENTS. We would like to thank P. Cushing for useful comments on the manuscript and English language modifications. This study was supported by grant no. MSM0021622416 provided by the Ministry of Education, Youth and Sports of the Czech Republic.

\section{REFERENCES}

Austin A.D. 1984: Life history of Clubiona robusta L. Koch and related species (Araneae, Clubionidae) in South Australia. $J$. Arachnol. 12: 87-104.

BlandeNIER G. \& FüRST P.A. 1998: Ballooning spiders caught by a suction trap in an agricultural landscape in Switzerland. In Selden P.A. (ed.): Proceedings of the 17th European Colloquium of Arachnology. British Arachnological Society, Burnham Beeches, Bucks, pp. 177-186.

BonARIC J.C. 1974: Notes sur une araignée myrmécocomimétique du genre Phrurolithus (Araneae, Clubionidae). Bull. Soc. Zool. Fr. 99: 637-643.

BRIstowe W.S. 1941: The Comity of Spiders II. Ray Society, London, 332 pp.

Ceccarelli F.S. 2008: Behavioral mimicry in Myrmarachne species (Araneae, Salticidae) from North Queensland, Australia. J. Arachnol. 36: 344-351.

Cloudsley-Thompson J.L. 1995: A review of the anti-predator devices of spiders. Bull. Br. Arachnol. Soc. 10(3): 81-96.

Collingwood C.A. \& Prince A. 1998: A guide to ants of continental Portugal (Hymenoptera: Formicidae). Bol. Soc. Port. Entomol. (Suppl.) 5: 1-49.

CUSHING P.E. 1997: Myrmecomorphy and myrmecophily in spiders: A review. Fla Entomol. 80: 165-193.

CutLer B. 1987: A revision of the American species of the antlike jumping spider genus Synageles (Araneae, Salticidae). $J$. Arachnol. 15: 321-348.

Dittrich W., Gilbert F., Green P., McGregor P. \& Grewcock D. 1993: Imperfect mimicry: a pigeon's perspective. Proc. $R$. Soc. Lond (B) 251: 195-200.

Edmunds M. 1974: Defence in Animals. A Survey of AntiPredator Defences. Longman, New York, 357 pp.

EDMunds M. 1978: On the association between Myrmarachne spp. (Salticidae) and ants. Bull. Br. Arachnol. Soc. 4: 149-160.

EDMunds M. 2000: Why are there good and poor mimics? Biol. J. Linn. Soc. 70: 459-466.

Edwards G.B. 1984: Mimicry of velvet ants (Hymenoptera: Mutillidae) by jumping spiders (Araneae: Salticidae). Peckhamia 2(4): 46-49.

EngelhardT W. 1970: Gestalt und Lebensweise der "Ameisenspinne" Synageles venator (Lucas) Zugleich ein 
Beitrag zur Ameisenmimikryforschung. Zool. Anz. 185: 321-334.

Exline H. \& Levi H.W. 1962: American spiders of the genus Argyrodes (Araneae Theridiidae). Bull. Mus. Comp. Zool. 127: 75-204.

Foelix R.F. 1996: Biology of Spiders. Oxford University Press, New York, 330 pp.

Gilbert F. 2005: The evolution of imperfect mimicry. In Fellowes M.D.E., Holloway G.J. \& Rolff J. (eds): Insect Evolutionary Ecology. CABI, Wallingford, pp. 231-288.

Grimm U. 1985: Die Gnaphosidae Mitteleuropas (Arachnida, Araneae). Abh. Natwiss. Ver. Hambg. 26: 1-318.

HARKNESS R.D. 1977: Further observations on the relation between an ant, Cataglyphis bicolor (F.) (Hymenoptera: Formicidae) and a spider, Zodarion frenatum (Simon) (Araneae: Zodariidae). Entomol. Mon. Mag. 112: 111-123.

HEAL J.R. 1989: Variation and seasonal changes in hoverfly species: interactions between temperature, age and genotype. Biol. J. Linn. Soc. 36: 251-269.

Heimer S. \& Nentwig W. 1991: Spinnen Mitteleuropas. Paul Parey, Berlin, $544 \mathrm{pp}$.

Holen O.H. \& Johnstone R.A. 2004: The evolution of mimicry under constraints. Am. Nat. 164: 598-613.

Hölldobler B. \& Wilson E.O. 1990: The Ants. Springer, Berlin, $732 \mathrm{pp}$.

HuseYnov E.F.O. 2006: The prey of the lynx spider Oxyopes globifer (Araneae, Oxyopidae) associated with a semidesert dwarf shrub in Azerbaijan. J. Arachnol. 34: 422-426.

JACKSON R.R. 1986: The biology of ant-like jumping spiders (Araneae, Salticidae): prey and predatory behaviour of Myrmarachne with particular attention to $M$. lupata from Queensland. Zool. J. Linn. Soc. 88: 179-190.

JACKSON R.R., NELSON X.J. \& SALM K. 2008: The natural history of Myrmarachne melanotarsa, a social ant-mimicking jumping spider. N. Z. J. Zool. 35: 225-235.

JoCQUÉ R. 1994: A termite mimicking spider: Thaumastochilus termitomimus n. sp. (Araneae, Zodariidae). J. Afr. Zool. 108: 321-327.

JoHNSTONE R.A. 2005: The evolution of inaccurate mimics. Nature 418: 524-526.

Kaston B.J. 1948: Spiders of Connecticut. State Geological and Natural History Survey, Hartford, 874 pp.

LEVI H.W. 1965: An unusual case of mimicry. Evolution 19: 261-262.

Marshall S.D. \& Gittleman J.L. 1994: Clutch size in spiders: is more better? Func. Ecol. 8: 118-124.

McIver J.D. \& Stonedahl G. 1993: Myrmecomorphy: Morphological and behavioral mimicry of ants. Annu. Rev. Entomol. 38: $351-379$.

McNAB B.K. 1984: Physiological convergence amongst anteating and termite-eating mammals. J. Zool. Lond. 203: 485-510.

Nelson X.J., Jackson R.R., Edwards G.B. \& Barrion A. 2005: Living with the enemy: jumping spiders that mimic weaver ants. J. Arachnol. 33: 813-819.
Nielsen E. 1932: The Biology of Spiders, with Special Reference to the Danish Fauna. Vol. 1, 2. Levin \& Munskgaard, Copenhagen, $248+723$ pp., 551 figs.

OLIVEIRA P.S. 1988: Ant-mimicry in some Brazilian salticid and clubionid spiders (Araneae: Salticidae, Clubionidae). Biol. J. Linn. Soc. 33: 1-15.

Oliveira P.S. \& SAZIMA I. 1985: Ant-hunting behaviour in spiders with emphasis on Strophius nigricans (Thomisidae). Bull. Br. Arachnol. Soc. 6: 309-312.

Peскнam G.W. \& Peскham E.G. 1889: Ant-like spiders of the family Attidae. Occas. Pap. Nat. Hist. Soc. Wis. 2: 3-11.

PéÁr S. \& JARAB M. 2011: Assessment of visual and behavioral resemblance in inaccurate myrmecomorphic spiders (Araneae). Invert. Biol. 130: 83-90.

PekÁr S. \& Král J. 2002: Mimicry complex in two central European zodariid spiders (Araneae: Zodariidae): how Zodarion deceives ants. Biol. J. Linn. Soc. 75: 517-532.

PekÁr S., Král J. \& LuBin Y.D. 2005: Natural history and karyotype of some ant-eating zodariid spiders (Araneae, Zodariidae) from Israel. J. Arachnol. 33: 50-62.

Platnick N.I. 2009: The World Spider Catalog, version 9.5. American Museum of Natural History, online at http:// research.amnh.org/entomology/spiders/catalog/index.html

Pocock R.I. 1909: Mimicry in spiders. J. Linn. Soc. Zool. 30: 256-270.

Pollard S.D. \& JACKSON R.R. 1982: The biology of Clubiona cambridgei (Araneae, Clubionidae): Intraspecific interactions. N. Z. J. Ecol. 5: 44-50.

ReISKIND J. 1970: Multiple mimetic forms in an ant-mimicking clubionid spider. Science 169: 587-588.

Ruxton G.D., Sherratt T.N. \& Speed M.P. 2004: Avoiding Attack. The Evolutionary Ecology of Crypsis, Warning Signals and Mimicry. Oxford University Press, Oxford, 249 pp.

SeIFERT B. 1996: Ameisen beobachten, bestimmen. Naturbuch Verlag, Augsburg, 352 pp.

SOYER B. 1943: Contribution a l'étude éthologique et écologique des Araignées de la provence occidentale. I. Quelques Araignées myrmécophages des environs de Marseille. Bull. Mus. Hist. Nat. Marseille 13: 51-55.

TRAUTNER J. 1994: Zum Beutespektrum von Gnaphosa lucifuga (Araneae: Gnaphosidae). Arachnol. Mitt. 7: 41-44.

TURNER J.R.G. 1978: Why male butterflies are non-mimetic: natural selection, sexual selection, group selection, modification and sieving. Biol. J. Linn. Soc. 10: 385-432.

WunderLICH J. 1979: Revision der europäischen Arten der Gattung Micaria Westring 1851, mit Anmerkungen zu den überigen paläarktischen Arten (Arachnida: Araneida: Gnaphosidae). Zool. Beitr. 25: 233-341.

WunderLich J. 1992: Die Spinnen-Fauna der Makaronesischen Inseln: Taxonomie, Ökologie, Biogeographie und Evolution. Beitr. Araneol. 1: 1-619.

WUNDERLICH J. 1994: Über "Ameisenspinnen" in Mitteleuropa (Arachnida: Araneae). Beitr. Araneol. 4: 447-470.

Zolnerowich G. \& Horner N.V. 1985: Gnaphosid spiders of North-central Texas (Araneae, Gnaphosidae). J. Arachnol. 13: 79-85.

Received August 9, 2010; revised and accepted November 9, 2010 